\title{
Chapter authors and other participating project team members
}

\section{OECD}

Nick Johnstone (Project Leader), Empirical Policy Analysis Unit, National Policies Division, OECD Environment Directorate

Julien Labonne, Empirical Policy Analysis Unit, National Policies Division, OECD Environment Directorate

Pascale Scapecchi, Empirical Policy Analysis Unit, National Policies Division, OECD Environment Directorate

\section{CANADA}

Irene Henriques, Schulich School of Business, York University

Perry Sadorsky, Schulich School of Business, York University

\section{FRANCE}

Matthieu Glachant, Centre d'Economie Industrielle, Ecole des Mines de Paris

Nicolas Riedinger, French Ministry of Industry (SESSI), Montreuil

Céline Serravalle, Institut National des Statistiques, et Etudes Economiques

Frédérique Vincent, Ecole des Mines de Paris, Institut Superieur d'Ingenierie et de Gestion de l'Environnement 


\section{GERMANY}

Manuel Frondel, Rheinisch-Westfälisches Institut für Wirtschaftsforschung (RWI), Essen, Environment and Resources Division

Jens Horbach, Professor of Economics, University of Applied Sciences Anhalt

Klaus Rennings, Centre for European Economic Research (ZEW), Research Area Environmental and Resource Economics, Environmental Management

\section{HUNGARY}

Sandor Kerekes, Department of Environmental Economics and Technology, Budapest University of Economic Sciences and Public, Administration

\section{JAPAN}

Toshi H. Arimura, Department of Economics, Sophia University

Akira Hibiki, Environmental Economics Section, Social Environmental Systems Division, National Institute for Environmental Studies

\section{NORWAY}

Haakon Flaaten, Norwegian School of Management BI

Bjarne Ytterhus, Norwegian School of Management BI

\section{UNITED STATES}

Nicole Darnall, Department of Environmental Science and Policy, George Mason University

G. Jason Jolley, Department of Public Administration, North Carolina State University

Alexei Pavlichev, Department of Public Administration, North Carolina State University 